\section{BRAZIULIAN JOURNAL \\ OF MEDICAL AND BIOLOGICAL RESHARCH}

www.bjournal.com.br
ISSN 0100-879X

Volume 43 (12) 1135-1244 December 2010

BIOMEDICAL SCIENCES

AND

CLINICAL INVESTIGATION

Braz J Med Biol Res, December 2010, Volume 43(12) 1184-1192

doi: 10.1590/S0100-879X2010007500121

Antinociceptive effect on mice of the hydroalcoholic fraction and (-) epicatechin obtained from Combretum leprosum Mart \& Eich

L.S. Lopes, R.B. Marques, S.S. Pereira, M.C.C. Ayres, M.H. Chaves, A.J. Cavalheiro, G.M. Vieira Júnior and F.R.C. Almeida

The Brazilian Journal of Medical and Biological Research is partially financed by

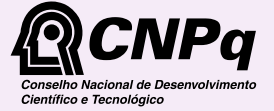

Ministério

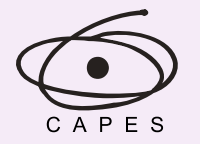

Ministério da Educação

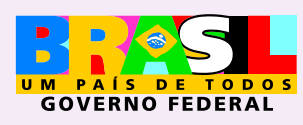

GOVERNO FEDERAL

\section{TFAPESP}

Institutional Sponsors
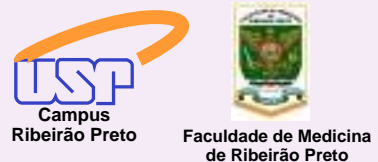

$$
\text { an }
$$

Hots ite of proteomics metabolomics developped by:

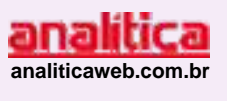

Thermo
SCIENTIFIC 


\title{
Antinociceptive effect on mice of the hydroalcoholic fraction and (-) epicatechin obtained from Combretum leprosum Mart \& Eich
}

\author{
L.S. Lopes ${ }^{1}$, R.B. Marques ${ }^{1}$, S.S. Pereira1, M.C.C. Ayres², M.H. Chaves², \\ A.J. Cavalheiro ${ }^{3}$, G.M. Vieira Júnior ${ }^{3}$ and F.R.C. Almeida ${ }^{1}$ \\ ${ }^{1}$ Núcleo de Pesquisa com Plantas Medicinais, Centro de Ciências da Sáude, \\ 2Departamento de Química, Centro de Ciências da Natureza, \\ Universidade Federal do Piauí, Teresina, PI, Brasil \\ 3 Instituto de Química, Universidade Estadual Paulista, Araraquara, SP, Brasil
}

\begin{abstract}
Previous studies on Combretum leprosum, a tree growing in the Northeastern states of Brazil, have shown antinociceptive effects of the ethanol extract of its leaves and bark, but studies examining its constituents are rare. The objective of this study was to evaluate the antinociceptive effect of the hydroalcoholic fraction (HF) of one of its constituents, the flavonoid (-) epicatechin (EPI), administered orally to mice (20-30 g) in models of chemical nociception, and the possible mechanisms involved. Different doses of HF (62.5 to $500 \mathrm{mg} / \mathrm{kg})$ and EPI (12.5 to $50 \mathrm{mg} / \mathrm{kg})$ were evaluated in models of abdominal writhing, glutamate, capsaicin, and formalin in animals pretreated with different antagonists: naloxone, ondansetron, yohimbine, ketanserin, pindolol, atropine, and caffeine in the abdominal writhing test. To determine the role of nitric oxide, the animals were pretreated with $\mathrm{L}$-arginine $(600 \mathrm{mg} / \mathrm{kg}, \mathrm{ip})$ in the glutamate test. The HF was effective $(P<0.05)$ in all protocols at different doses and EPI was effective in the abdominal writhing, capsaicin and glutamate tests $(P<0.05)$ at doses of 25 and $50 \mathrm{mg} / \mathrm{kg}$. However, in the formalin test it was only effective in the second phase at a dose of $25 \mathrm{mg} / \mathrm{kg}$. The antinociceptive effect of HF was inhibited when HF was associated with yohimbine $(0.15 \mathrm{mg} / \mathrm{kg})$, ketanserine $(0.03 \mathrm{mg} / \mathrm{kg})$, and L-arginine $(600 \mathrm{mg} / \mathrm{kg})$, but not with the other antagonists. HF and EPI were effective in models of chemical nociception, with the suggested participation of the adrenergic, serotonergic and nitrergic systems in the antinociceptive effect of HF.
\end{abstract}

Key words: Combretum leprosum; Epicatechin; Antinociceptive; Serotonin; Nitric oxide

\section{Introduction}

Combretum leprosum Mart \& Eich (Combretaceae) is found in the Northeastern region of Brazil, where it is known as mufumbo. Its leaves and bark are used as hemostatics, sedatives and in the treatment of pertussis and uterine bleeding. Chemically, flavonoids (3',5'-dihydroxy-3, 3', 7'-trimethoxyflavone, $3 \beta, 6 \beta$, 16 $\beta$-trihydroxylup-20(29)-ene) and triterpenes (arjunolic and malic acid) have been isolated from the flowers and leaves of this species $(1,2)$. Studies have shown that the ethanol extract of the bark and flowers, and a triterpene isolated from the flowers of $C$. leprosum have an antinociceptive effect on several models of acute pain in mice $(2,3)$. A gastroprotective action of ethanol extract of stem bark has also been observed (4). Other species of Combretum have antimicrobial, anticancer and anti-inflammatory activities (5). To date, there are no data on the pharmacological activities of fractions and major compounds obtained from $C$. leprosum's stem bark. According to Ayres (6), chromatographic fractionation of the hydroalcoholic fraction (HF) led to the isolation of (-)epicatechin (EPI) as the main constituent of pharmacological interest. EPI is a flavonoid known primarily for its antioxidant activity (7). However, other studies (8) have shown an analgesic effect of similar compounds, thus justifying the assessment of this substance in nociception models.

On the basis of these considerations, the objective of the present study was to determine the antinociceptive effect of the HF and EPI obtained from C. leprosum stem bark, and the mechanisms involved in this effect on animal models of acute pain.

Correspondence: L.S. Lopes, Núcleo de Pesquisa com Plantas Medicinais, Universidade Federal do Piauí, Av. Nossa Senhora de Fátima, s/n, 64049-550 Teresina, PI, Brasil. Fax: +55-86-3215-5560. E-mail: lucianofacid@hotmail.com

Received May 2, 2010. Accepted October 19, 2010. Available online November 5, 2010. Published December $20,2010$. 


\section{Material and Methods}

\section{Animals}

The acute pain tests were carried out on $20-$ to $30-\mathrm{g}$ male Swiss mice reared at the Medicinal Plants Research Center of the Federal University of Piauí. The animals were housed at $22 \pm 2^{\circ} \mathrm{C}$ on a 12-h light/dark cycle with free access to food and water. Animals were acclimatized to the laboratory for at least $2 \mathrm{~h}$ before testing and were used only once. The experiments were performed after approval of the protocol by the Institutional Ethics Committee (No. 011/2008) of the Universidade Federal do Piauí, Brazil, and were carried out in accordance with the current guidelines for the care of laboratory animals and the ethical guidelines for investigations of experimental pain in conscious animals (9). The number of animals and intensities of noxious stimuli used were the minimum necessary to demonstrate the consistent effects of the drug treatments.

\section{Plant material, identification and isolation of constituents}

Combretum leprosum was collected at the Agrarian Sciences Center, Federal University of Piauí (UFPI) in September 2007 (502'57.28"S, 4246'43.27"O at $93 \mathrm{~m}$ above sea level). After collection, a voucher specimen was identified and deposited in the Graziela Barroso Herbarium (TEPB 6216). Dried and powdered barks (1196 g) of $C$. leprosum were extracted six times by maceration with ethanol at room temperature (123 g, 10.3\%). The solvent was removed by evaporation under reduced pressure and part of the extract $(95 \mathrm{~g})$ was suspended in a mixture of $\mathrm{H}_{2} \mathrm{O} / \mathrm{MeOH}(2: 1)$ and subjected to partition with ethyl acetate, yielding the $\mathrm{H}_{2} \mathrm{O} / \mathrm{MeOH}(27.0 \mathrm{~g}, 28.4 \%)$ and $\mathrm{EtAcO}$ fractions. The latter was concentrated and suspended in $\mathrm{MeOH} / \mathrm{H}_{2} \mathrm{O}(9: 1)$ and extracted with hexane, yielding the hexane $(7.0 \mathrm{~g}, 7.4 \%)$, and hydroalcoholic $(52.0 \mathrm{~g}, 54.7 \%)$ fractions. Part of the hydroalcoholic fractions $(11 \mathrm{~g})$ was applied to a silica gel column $(4.5 \times 55 \mathrm{~cm})$ eluted with $\mathrm{CHCl}_{3} / \mathrm{MeOH}$, in order of increasing polarity, yielding 139 fractions (125 $\mathrm{mL}$ each) collected as follows: 1-10 $\left(\mathrm{CHCl}_{3}, 100 \%\right), 11-22\left(\mathrm{CHCl}_{3} / \mathrm{MeOH}, 98: 2\right), 23-34\left(\mathrm{CHCl}_{3} /\right.$ $\mathrm{MeOH}, 95: 5)$, 46-79 ( $\left.\mathrm{CHCl}_{3} / \mathrm{MeOH}, 9: 1\right), 80-115\left(\mathrm{CHCl}_{3} /\right.$ $\left.\mathrm{MeOH}, 8: 2), 116-135 \mathrm{CHCl}_{3} / \mathrm{MeOH}, 7: 3\right), 136-139(\mathrm{MeOH}$, $100 \%)$. Fraction $\mathrm{G}\left(56-79,438 \mathrm{mg}, \mathrm{CHCl}_{3} / \mathrm{MeOH}, 9: 1\right)$ was applied to an RP-18 column using a $\mathrm{H}_{2} \mathrm{O} / \mathrm{MeOH}(6: 4)$ solvent system to yield fraction $\mathrm{G} 2(315 \mathrm{mg})$. This fraction was re-purified on a Sephadex $\mathrm{LH}-20$ column eluted with $\mathrm{MeOH}(100 \%)$ to yield EPI (135 mg, 1.23\%), identified by ${ }^{1} \mathrm{H}$ and ${ }^{13} \mathrm{C}$ NMR spectroscopic analyses and compared with literature values $(10,11)$. The absolute configuration of the EPI (Figure 1) was determined by circular dichroism. Thin layer chromatography of the hydroalcoholic fraction revealed other components such as carbohydrates and tannins, but no substance of pharmacological interest for this study was detected.

\section{HPLC analysis of HF}

Elution was performed with $\mathrm{MeOH} / \mathrm{H}_{2} \mathrm{O}$, in a gradient elution mode $(5 \rightarrow 100 \%$ in $45 \mathrm{~min}$ ) plus an isocratic step of $100 \% \mathrm{MeOH}$ for 5 min to verify that there was no more substance in the column, at a flow rate of $1.0 \mathrm{~mL} / \mathrm{min}$, at room temperature $\left(25^{\circ} \mathrm{C}\right)$ and a $30-\mu \mathrm{L}$ injection of $\mathrm{HF}$ at a concentration of $5.0 \mathrm{mg} / \mathrm{mL}$. The chromatograms were monitored at $254 \mathrm{~nm}$ and the UV spectra were recorded from 200 to $600 \mathrm{~nm}$. The equipment used was Analytical reversed-phase HPLC, Shimadzu ${ }^{\circledR}$ prominence system (comprising a model LC-6AD pump, a SIL-10AF autosampler, and an SPD-M20A photodiode array detector) fitted with a Phenomenex Luna C18(2) column (250 mm x 4.6 $\mathrm{mm}, 5 \mu \mathrm{m}$ ), with control and data handling managed by the LC solution software (Figure 2A,B).

\section{Drugs}

The following substances were used: naloxone (an opioid antagonist; Sigma, USA), ondansetron (a $5-\mathrm{HT}_{3}$ antagonist; Sigma), ketanserine (a $5-\mathrm{HT}_{2}$ antagonist; Sigma), clonidine (an $\alpha 2$ agonist; Sigma), yohimbine (an $\alpha 2$ adrenergic receptor antagonist; Sigma), pindolol (a 5- $\mathrm{HT}_{1}$ and $\beta$-adrenergic antagonist; Sigma), atropine (a muscarinic antagonist; Cristália, Brazil), morphine (an opioid agonist; Cristália), MK 801 (an NMDA receptor antagonist; Sigma), caffeine (a nonselective adenosine receptor antagonist; Sigma), L-arginine (a nitric oxide precursor; Sigma), Lnitro arginine (a nitric oxide synthase inhibitor; Sigma), $\mathrm{D}$-arginine (an inactive isomer of L-arginine; Sigma), glutamate (an excitatory amino acid; Sigma), and capsaicin (a transient receptor potential vanilloid (TRPV) receptor agonist; Sigma).

For the pharmacological studies, HF and EPI were suspended in a $0.9 \% \mathrm{NaCl}$ and $1 \%$ dimethylsulfoxide (DMSO) solution. The doses employed are reported as $\mathrm{mg}$ $\mathrm{HF}$ and EPI per kg body weight. Capsaicin was dissolved in a mixture of $2 \%$ Tween $80,2 \%$ DMSO and $1 \%$ methyl alcohol. Drugs were administered orally $(p o)$ at different doses $(62.5$ to $500 \mathrm{mg} / \mathrm{kg}$ for HF and $12.5,25$ to $50 \mathrm{mg} / \mathrm{kg}$ for EPI) to construct the dose-response curves. There is

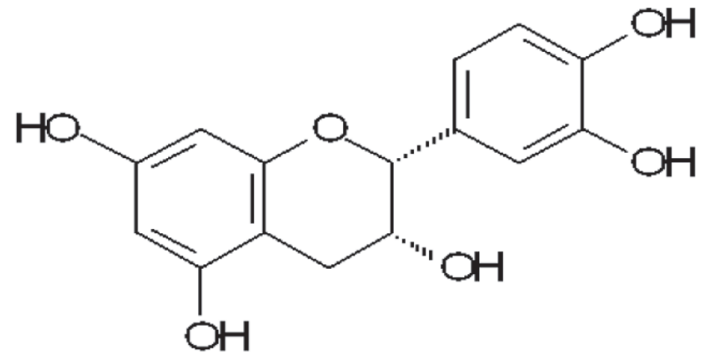

Figure 1. Structure of EPI (-) epicatechin isolated from Combretum leprosum Mart \& Eich. 
evidence that EPI has good oral absorption and its peak plasma concentration is achieved within about $60 \mathrm{~min}(7,12)$, coinciding with the period of observation of animals in the experimental protocols.

\section{Abdominal constriction response caused by intraperitoneal injection of acetic acid}

The procedure was similar to a previously described method (13). The mice ( $N=7-8)$ were adapted and pretreated with vehicle $(0.1 \mathrm{~mL} / 10 \mathrm{~g}), \operatorname{HF}(125,250$, and 500 $\mathrm{mg} / \mathrm{kg}, p o)$, and $\mathrm{EPI}(12.5,25$, and $50 \mathrm{mg} / \mathrm{kg}, \mathrm{po}) 60 \mathrm{~min}$ before the intraperitoneal (ip) administration of $0.75 \%$ acetic acid. The strength of the elicited antinociceptive effect was compared to that of an effective dose of morphine $(2.5 \mathrm{mg} /$ $\mathrm{kg}, \mathrm{sc}$ ) administered $30 \mathrm{~min}$ before the acetic acid injection. The total number of writhings was counted over a period of 20 min after injection of acetic acid.

\section{Nociception induced by glutamate}

The procedure used was similar to that previously described (14). The animals $(\mathrm{N}=6-7)$ received an intraplantar injection $(\mathrm{ip} /)$ of glutamate $(20 \mathrm{mmol} / \mathrm{paw}) 60 \mathrm{~min}$ after

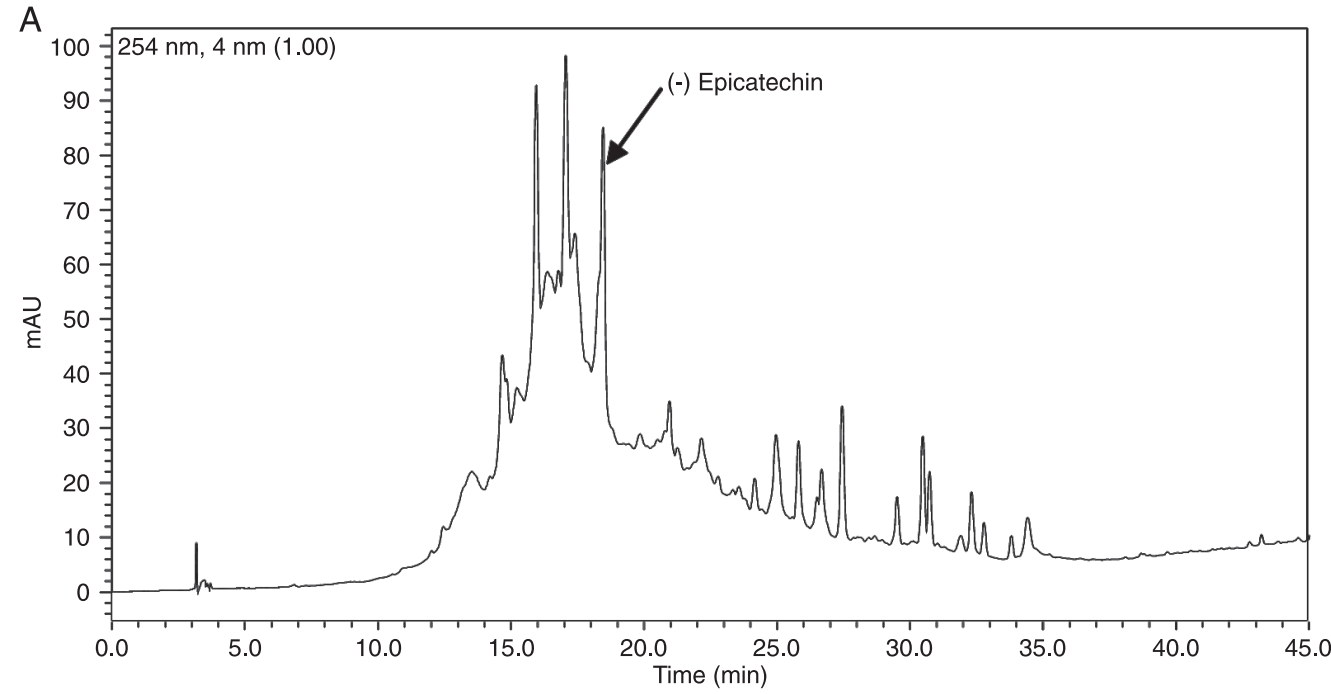

B

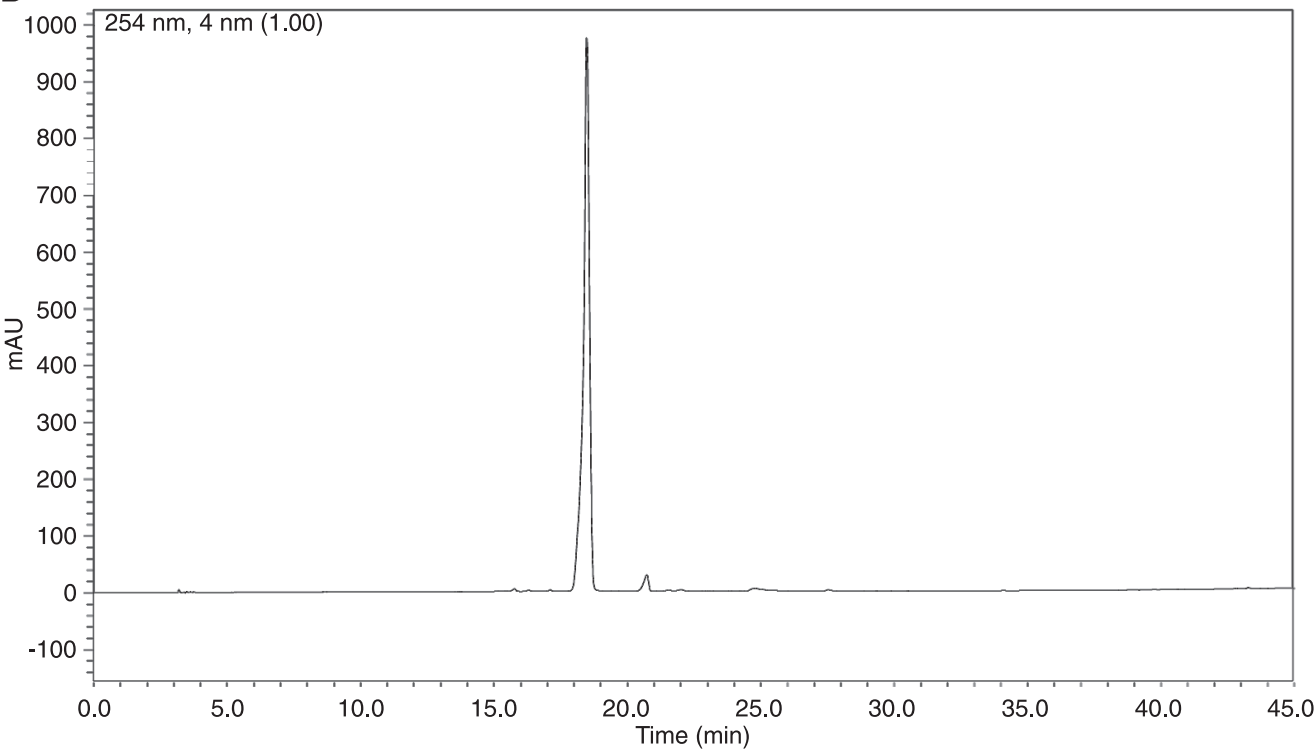

Figure 2. A, HPLC chromatogram obtained from hydroalcoholic fraction of stem bark from Combretum leprosum Mart \& Eich. B, HPLC chromatogram of (-) epicatechin standard (Sigma-Aldrich). The column was C18 with elution in $\mathrm{MeOH} / \mathrm{H}_{2} \mathrm{O}$ gradient. 
administration of vehicle $(0.1 \mathrm{~mL} / 10 \mathrm{~g}), \operatorname{HF}(62.5,125,250$, and $500 \mathrm{mg} / \mathrm{kg}, \mathrm{po}$ ) or EPI (25 and $50 \mathrm{mg} / \mathrm{kg}, \mathrm{po}$ ) and 30 min after the administration of MK $801(0.03 \mathrm{mg} / \mathrm{kg}$, ip) as a positive control. Animals were observed individually for 15 min following glutamate injection. The amount of time spent licking the injected paw was taken to indicate nociception.

\section{Capsaicin test}

HF and EPI were tested against capsaicin-induced licking in the mouse paw. The procedure used was similar to that described previously $(2,14)$. After an adaptation period, the animals $(\mathrm{N}=6-7)$ were treated with vehicle $(0.1$ $\mathrm{mL} / 10 \mathrm{~g}, \mathrm{po}), \mathrm{HF}(62.5,125,250$, and $500 \mathrm{mg} / \mathrm{kg}, \mathrm{po})$ or EPI (12.5, 25, and $50 \mathrm{mg} / \mathrm{kg}$, po) $60 \mathrm{~min}$ before capsaicin administration (20 $\mu \mathrm{L}, 2 \mu \mathrm{g} / \mathrm{paw})$, and the time (s) spent licking or biting the stimulated paw was measured for 5 min. Positive control animals received morphine $(5 \mathrm{mg} / \mathrm{kg}$, sc) 30 min before injection of the irritant.

\section{Formalin test}

The procedure was similar to a previously described method (13). Animals $(\mathrm{N}=6-7)$ were treated with vehicle $(0.1 \mathrm{~mL} / 10 \mathrm{~g}, p o), \operatorname{HF}(62.5,125,250$, and $500 \mathrm{mg} / \mathrm{kg}, \mathrm{po})$ or $\operatorname{EPI}(12.5,25$, and $50 \mathrm{mg} / \mathrm{kg}$, po) 60 min before the injection of $2 \%$ formalin $(20 \mu \mathrm{L} / \mathrm{paw}, \mathrm{ip} /)$. Morphine was used as a positive control drug administered at the dose of $5 \mathrm{mg} / \mathrm{kg}$, sc, 30 min before the test. Immediately after the formalin injection, the animal was observed for pain-related behavior. The time (s) spent licking or biting the injected hind paw was measured during the first phase (0-5 min, neurogenic phase) and the second phase (15-30 min, tonic phase).

\section{Analysis of possible antinociceptive mechanisms of hydroalcoholic fraction}

To assess the possible mechanisms involved in the antinociceptive action of HF, mice were previously treated with different drugs in the acetic acid model $(\mathrm{N}=6-7)$. The doses of the drugs used were selected on the basis of literature data and of previous results from our laboratory (2,14-16). To determine the possible participation of different systems, we used antagonists of various receptors administered Sc 20 min before the $\mathrm{HF}$. We used naloxone (2 $\mathrm{mg} / \mathrm{kg}$ ), an antagonist of opioid receptors; ondansetron $(0.5 \mathrm{mg} / \mathrm{kg})$, an antagonist of $5-\mathrm{HT}_{3}$ receptors; ketanserine $(0.3 \mathrm{mg} / \mathrm{kg})$, an antagonist of $5-\mathrm{HT}_{2 \mathrm{~A}}$ receptors; pindolol (1 $\mathrm{mg} / \mathrm{kg})$, an antagonist of $5-\mathrm{HT} 1_{\mathrm{a}} / 1_{\mathrm{b}}$ receptors; atropine $(0.1 \mathrm{mg} / \mathrm{kg})$, an antagonist of muscarinic receptors; yohimbine
$(0.15 \mathrm{mg} / \mathrm{kg})$, an antagonist of $\alpha 2$ adrenergic receptors, and caffeine $(3 \mathrm{mg} / \mathrm{kg})$, an antagonist of adenosine receptors. To evaluate the effect of HF on the L-arginine/nitric oxide (NO) pathway, we used the model of glutamate-induced nociception ( $\mathrm{N}=6-7)$, a more specific model for this assessment. Animals were pretreated with L-arginine (600 $\mathrm{mg} / \mathrm{kg}, i p)$, a precursor of NO or D-arginine $(600 \mathrm{mg} / \mathrm{kg}$, ip, an inactive isomer of L-arginine), 20 min before the HF (250 mg/kg, po) or L-NOARG (75 mg/kg, ip).

\section{Measurement of motor performance and locomotor activity}

To evaluate some nonspecific muscle-relaxant or sedative effects of HF, we applied the open-field (30 x 30 $x 15 \mathrm{~cm}$ ) and the rotarod tests and observed the number of quarters invaded for $5 \mathrm{~min}$ and the residence time in the rotating rod at $12 \mathrm{rpm} 60 \mathrm{~min}$ after the administration of HF (500 mg/kg, po), diazepam (4 mg/kg, ip) or vehicle $(0.1 \mathrm{~mL} / 10 \mathrm{~g}, p o)$. In the rotarod test, the cut-off time used was $60 \mathrm{~s}$. The animals were selected $24 \mathrm{~h}$ previously and those which did not remain on the bar for two consecutive periods of $60 \mathrm{~s}$ were not employed in the test.

\section{Data analysis}

Data are reported as means \pm SEM and were analyzed statistically by one- or two-way analysis of variance (ANOVA), followed by Bonferroni's test when appropriate, using the GraphPad software 5.0. The level of significance was set at $P<0.05$.

\section{Results}

\section{Writhing test}

HF reduced the number of writhings (Table 1) at doses

Table 1. Antinociceptive effect of the hydroalcoholic fraction (HF) of Combretum leprosum Mart \& Eich bark on acetic acid-induced writhing and the glutamate test in mice.

\begin{tabular}{|c|c|c|c|c|}
\hline \multirow[t]{2}{*}{ Treatment } & \multicolumn{2}{|c|}{ No. of writhings } & \multicolumn{2}{|c|}{ Licking time (s) } \\
\hline & Mean \pm SEM & $\%$ Inhibition & Mean \pm SEM & $\%$ Inhibition \\
\hline \multicolumn{5}{|l|}{ HF } \\
\hline $500 \mathrm{mg} / \mathrm{kg}$, po & $26.87 \pm 3.98^{*}$ & $55.5 \%$ & $28.41 \pm 8.56^{*}$ & $71.1 \%$ \\
\hline $250 \mathrm{mg} / \mathrm{kg}$, po & $34.62 \pm 4.44^{*}$ & $42.6 \%$ & $41.03 \pm 8.16^{*}$ & $51.5 \%$ \\
\hline $125 \mathrm{mg} / \mathrm{kg}$, po & $49.85 \pm 7.72$ & $17.4 \%$ & $49.94 \pm 10.81^{*}$ & $40.9 \%$ \\
\hline $62.5 \mathrm{mg} / \mathrm{kg}, p o$ & - & - & $73.33 \pm 12.12$ & $13.2 \%$ \\
\hline Vehicle $(0.1 \mathrm{~mL} / 10 \mathrm{~g}, \mathrm{po})$ & $60.30 \pm 2.30$ & - & $86.80 \pm 6.20$ & - \\
\hline Morphine $(2.5 \mathrm{mg} / \mathrm{kg}, \mathrm{sc})$ & $8.70 \pm 2.97^{*}$ & $85.7 \%$ & - & - \\
\hline MK 801 (0.03 mg/kg, ip) & - & - & $19.21 \pm 3.96^{*}$ & $77.3 \%$ \\
\hline
\end{tabular}

Animals $(\mathrm{N}=6-7)$ were pretreated with $\mathrm{HF}(62.5-500 \mathrm{mg} / \mathrm{kg}, \mathrm{po})$ or vehicle $(0.1 \mathrm{~mL} / 10 \mathrm{~g}, \mathrm{po})$ $60 \mathrm{~min}$ before the injection of acetic acid $(0.75 \%, 0.1 \mathrm{~mL} / 10 \mathrm{~g}$, ip) or glutamate $(20 \mathrm{mmol} /$ paw, ip/). The total number of writhings was determined for 20 min after injection of acetic acid or the amount of time spent licking the injected paw was determined. Data are reported as means \pm SEM. ${ }^{*} P<0.05$ compared to vehicle (one-way ANOVA, Bonferroni's test). 
of $500 \mathrm{mg} / \mathrm{kg}$, po $(26.87 \pm 3.98)$ and $250 \mathrm{mg} / \mathrm{kg}$, po (34.62 \pm 4.44 ) but not at the dose of $125 \mathrm{mg} / \mathrm{kg}$, po, when compared to vehicle $(60.30 \pm 2.30)$. Morphine was used as a positive control $(2.5 \mathrm{mg} / \mathrm{kg}, \mathrm{sc})$ and caused a reduction in the response of the animal $(8.70 \pm 2.97)$. Figure $3 \mathrm{~A}$ shows that EPI was very effective in reducing the number of writhings at doses of $25 \mathrm{mg} / \mathrm{kg}(20.00 \pm 4.60)$ and 50 $\mathrm{mg} / \mathrm{kg}(21.00 \pm 5.10)$ compared to vehicle $(52.88 \pm 3.88)$.
Morphine inhibited the writhing response induced by acetic acid $(6.80 \pm 2.45)$.

\section{Glutamate test}

The oral administration of HF also reduced the glutamate-induced neurogenic pain (Table 1) at doses of 500 $\mathrm{mg} / \mathrm{kg}$, po $(28.41 \pm 8.56), 250 \mathrm{mg} / \mathrm{kg}$, po $(41.03 \pm 8.16)$ and $125 \mathrm{mg} / \mathrm{kg}$, po (49.94 \pm 10.81$)$, but no significant ef-
A

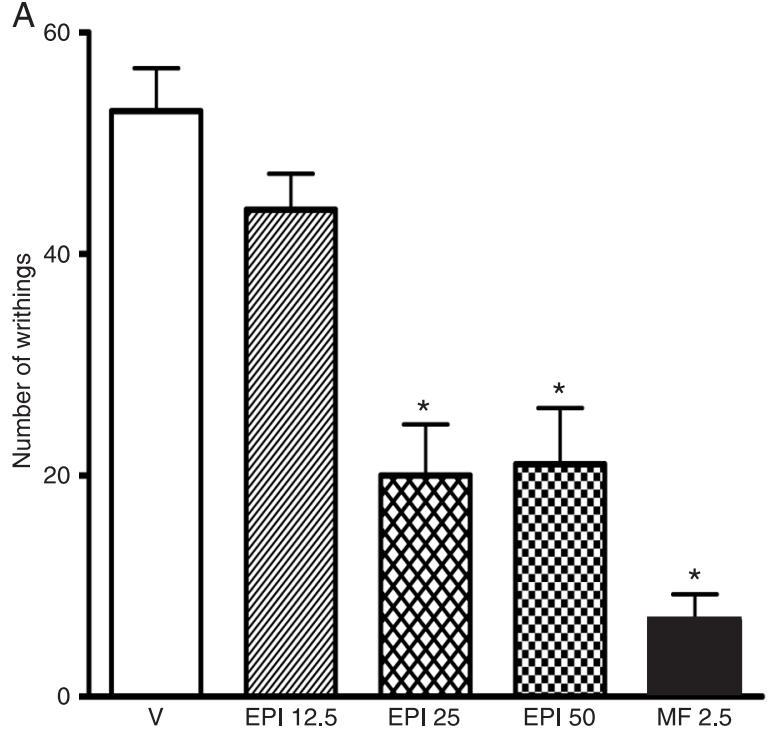

B

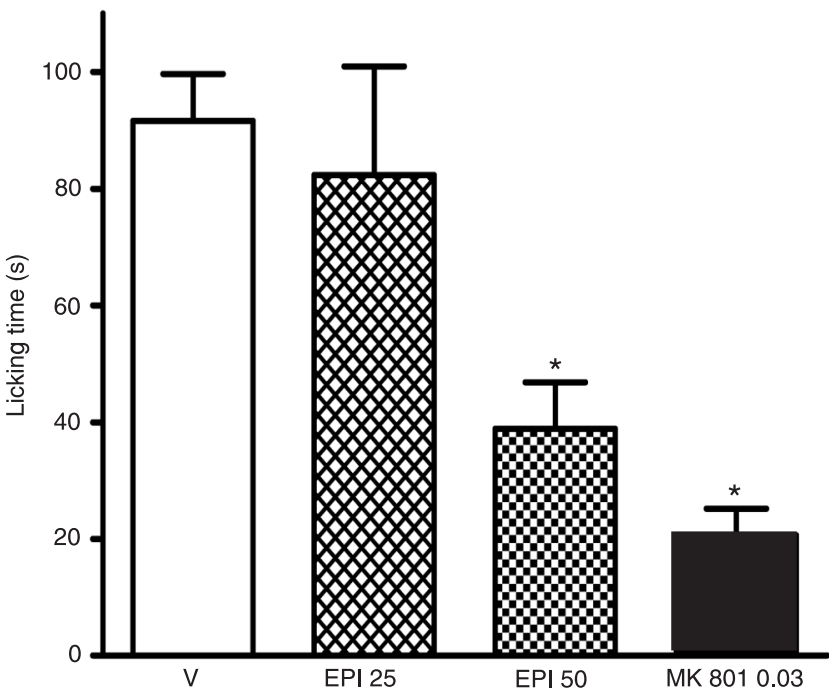

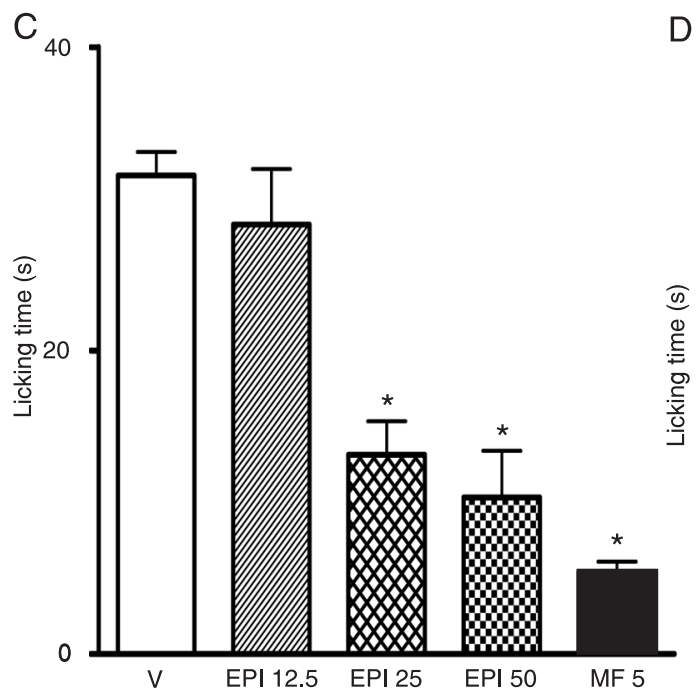

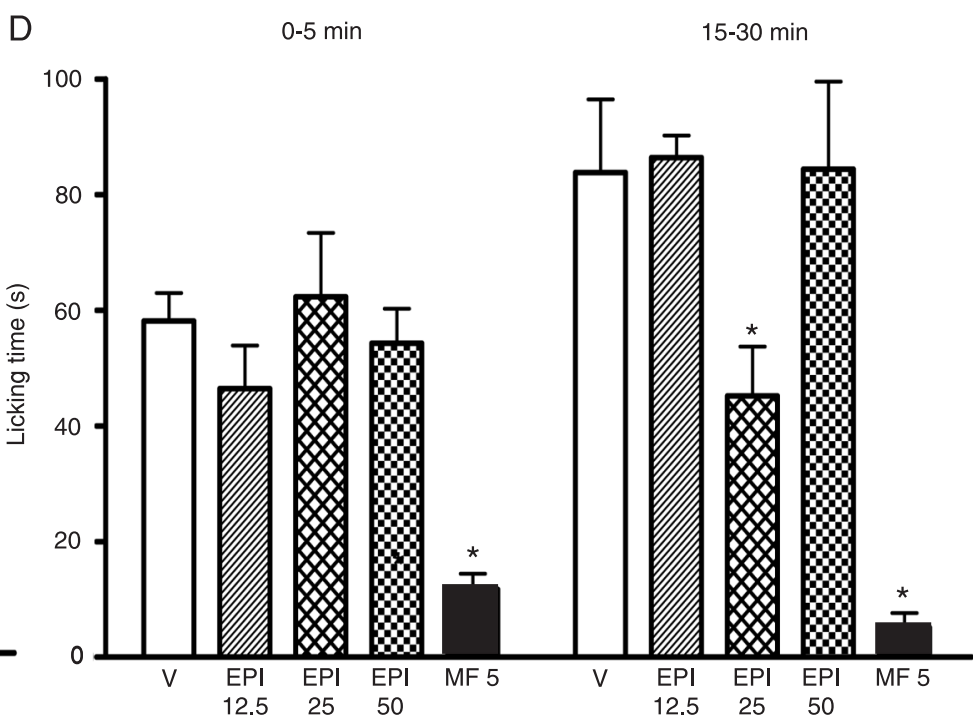

Figure 3. Antinociceptive effect of (-) epicatechin (EPI, $12.5-50 \mathrm{mg} / \mathrm{kg}$ ) and vehicle $(\mathrm{V}, 0.1 \mathrm{~mL} / 10 \mathrm{~g}$, po) administered orally against acetic acid (A, $20 \mathrm{~min}$ ), glutamate (B, $15 \mathrm{~min}$ ), capsaicin (C, $5 \mathrm{~min}$ ), or formalin-induced (D, 0-5 min, phase 1, and 15-30 min, phase 2) nociception in mice $(\mathrm{N}=6-8)$. EPI was administered $60 \mathrm{~min}$ before injection of the noxious agents. Positive control received morphine (MF, 2.5-5 mg/kg, sc) or MK $801(0.03 \mathrm{mg} / \mathrm{kg}, i p)$. The height of each column represents the mean \pm SEM. *P $<0.05$ compared to vehicle (one-way ANOVA, Bonferroni's test). 
fect was observed at $62.5 \mathrm{mg} / \mathrm{kg}$, po, when compared to vehicle $(86.80 \pm 6.20)$. MK $801(0.03 \mathrm{mg} / \mathrm{kg}$, ip) was used as positive control and showed a decrease of the response $(19.21 \pm 3.96)$. Similar results were observed with EPI (50 $\mathrm{mg} / \mathrm{kg}, \mathrm{po})$ in this model, with a significant effect $(38.86$
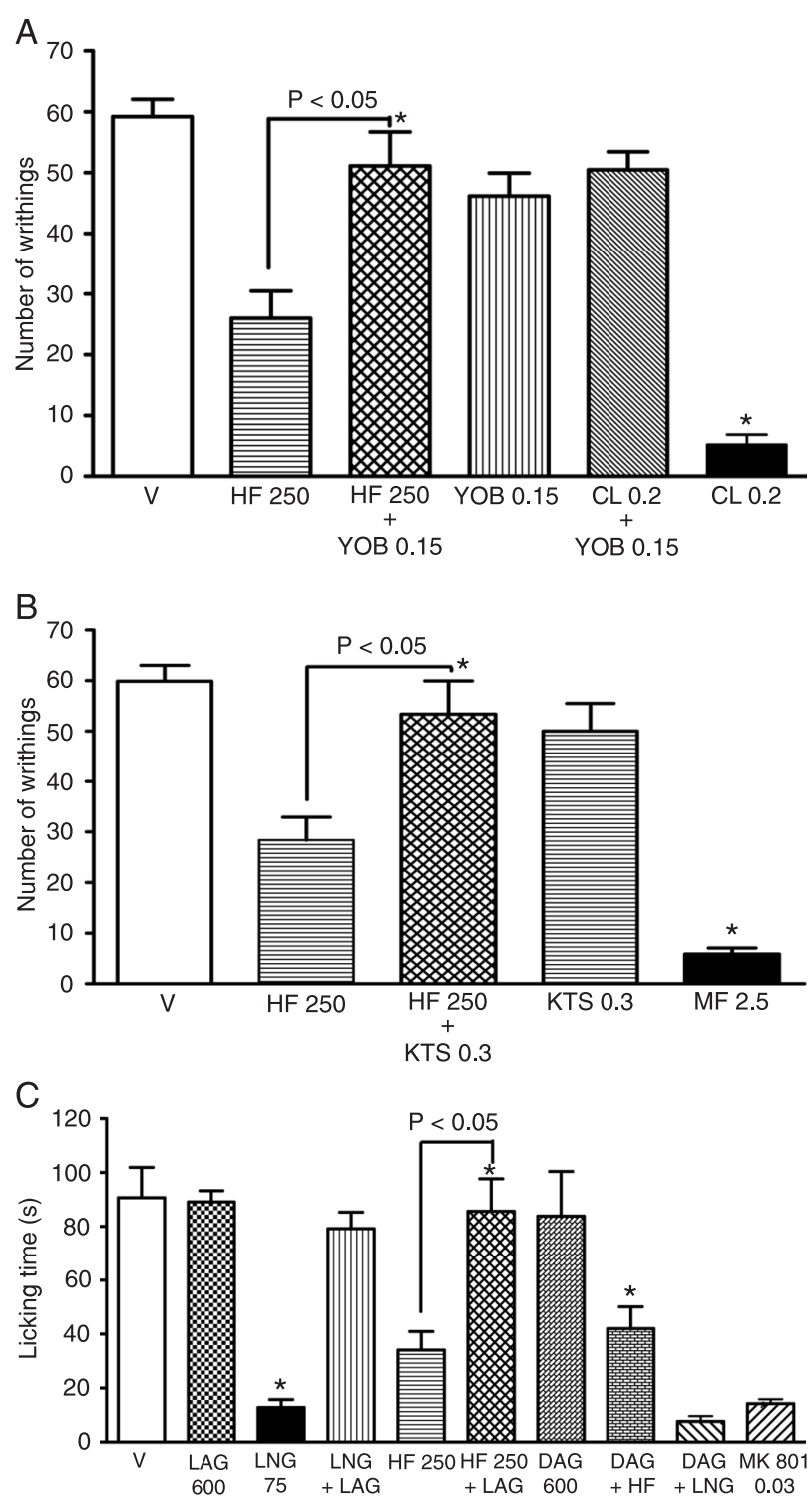

Figure 4. Effect of pretreatment of animals with $A$, yohimbine (YOB, $0.15 \mathrm{mg} / \mathrm{kg}, s c$ ); $B$, ketanserine (KTS, $0.3 \mathrm{mg} / \mathrm{kg}, s c$ ); $C$, Larginine (LAG, $600 \mathrm{mg} / \mathrm{kg}$, ip), and D-arginine (DAG, $600 \mathrm{mg} / \mathrm{kg}$, ip) on the antinociceptive profiles of the hydroalcoholic fraction (HF; $250 \mathrm{mg} / \mathrm{kg}, p o)$ against acetic acid-induced writhing $(0.75 \%$, ip) or glutamate-induced licking $(20 \mathrm{mmol} / \mathrm{paw}, \mathrm{ipl})$ in mice $(\mathrm{N}=$ 6-7). Clonidine ( $\mathrm{CL}, 0.2 \mathrm{mg} / \mathrm{kg}, s c)$, morphine (MF, $2.5 \mathrm{mg} / \mathrm{kg}, s c$ ), MK 801 (0.03 mg/kg, ip), and L-NOARG (LNG, $75 \mathrm{mg} / \mathrm{kg}, \mathrm{sc}$ ), were used as controls. $V=$ vehicle $(0.1 \mathrm{~mL} / 10 \mathrm{~g}, p o)$. Each column represents the mean \pm SEM. ${ }^{*} \mathrm{P}<0.005$ compared to HF (one-way ANOVA, Bonferroni's test). \pm 8.01 ), which did not occur at the dose of $25 \mathrm{mg} / \mathrm{kg}$, po (Figure 3B).

\section{Capsaicin test}

HF significantly reduced the capsaicin-induced nociception (Table 2) with oral doses of 500 (10.48 \pm 2.82$), 250$ $(13.56 \pm 4.32)$ and $125(20.36 \pm 3.68)$, but no significant effect was observed with $62.5 \mathrm{mg} / \mathrm{kg}$, po, compared to vehicle. Similar results were observed with EPI (25 and $50 \mathrm{mg} / \mathrm{kg}, \mathrm{po}$ ) in this model (Figure 3C), with a significant reduction of nociception (13.14 \pm 2.20 and $10.31 \pm 3.07$, respectively). Morphine was used as positive control and caused a reduction in the response $(5.37 \pm 0.71)$.

\section{Formalin test}

$\mathrm{HF}$ was effective in reducing formalin-induced nociception in both phases of the test (Table 2). Doses of 500 , 250 , and $125 \mathrm{mg} / \mathrm{kg}$ were effective in the first (27.35 \pm $5.06,26.29 \pm 4.36,27.90 \pm 12.53)$ and second phases $(19.87 \pm 11.09,33.88 \pm 11.95,30.45 \pm 12.39)$, respectively, compared to vehicle $(60.02 \pm 3.25$ and $83.35 \pm 11.62)$. This effect was not observed at the dose of $62.5 \mathrm{mg} / \mathrm{kg}$. On the other hand, Figure 3D shows that EPI $25 \mathrm{mg} / \mathrm{kg}$, po, had no antinociceptive effect in the first phase, but caused a reduction of the response during the second phase $(45.16$ $\pm 8.55)$ compared to vehicle $(58.13 \pm 4.82$ and $83.85 \pm$ 12.65). Similarly, morphine ( $5 \mathrm{mg} / \mathrm{kg}, \mathrm{sc})$ produced marked inhibition of both the neurogenic pain $(11.70 \pm 2.71)$ and inflammatory pain $(5.12 \pm 2.50)$.

\section{Analysis of possible antinociceptive mechanisms of hydroalcoholic fraction}

The results in Figure 4A-C show that pretreatment of animals with $0.15 \mathrm{mg} / \mathrm{kg}$ yohimbine, sc (51.12 \pm 5.57$)$ and $0.3 \mathrm{mg} / \mathrm{kg}$ ketanserine, sc (53.33 \pm 6.58$)$ significantly inhibited the antinociceptive effect of HF $(26.00 \pm 4.46)$ on acetic acid-induced writhing. However, pretreatment with caffeine (3 mg/kg, sc), atropine $(0.1 \mathrm{mg} / \mathrm{kg}, s c)$, pindolol (1 $\mathrm{mg} / \mathrm{kg} \mathrm{sc}$ ), ondansetron ( $0.5 \mathrm{mg} / \mathrm{kg}, \mathrm{sc})$, and naloxone (2 $\mathrm{mg} / \mathrm{kg}, \mathrm{sc}$ ) did not alter this effect (data not shown).

The role of the L-arginine/NO pathway in the antinociceptive effect of HF was investigated in the glutamate test. Pretreatment with the NO precursor L-arginine, $600 \mathrm{mg} / \mathrm{kg}$, ip, completely reversed the antinociception caused by 250 $\mathrm{mg} / \mathrm{kg} \mathrm{HF}$, ip (85.64 \pm 12.04$)$ but this effect was not observed with D-arginine (600 mg/kg, ip). The systemic treatment of the animals with L-arginine also produced significant inhibition $(79.20 \pm 6.10)$ of the antinociception caused by $75 \mathrm{mg} /$ kg L-NOARG, ip (12.82 \pm 2.89; Figure 4C).

\section{Evaluation of motor performance and locomotor activity}

$\mathrm{HF}(500 \mathrm{mg} / \mathrm{kg}, \mathrm{po})$ did not affect the motor performance in the rotarod task or the locomotor activity in the open-field test when compared with animals that received vehicle. 
Table 2. Effect of pretreatment with different doses of the hydroalcoholic fraction (HF) of Combretum leprosum Mart \& Eich bark (62.5$500 \mathrm{mg} / \mathrm{kg}, \mathrm{po}$ ) on capsaicin- or formalin-induced licking in mice.

\begin{tabular}{|c|c|c|c|c|c|c|}
\hline \multirow[t]{3}{*}{ Treatment } & \multirow{2}{*}{\multicolumn{2}{|c|}{$\frac{\text { Capsaicin-induced licking time (s) }}{0-5 \mathrm{~min}}$}} & \multicolumn{4}{|c|}{ Formalin-induced licking time (s) } \\
\hline & & & \multicolumn{2}{|c|}{$0-5 \min ($ Phase 1$)$} & \multicolumn{2}{|c|}{ 15-30 min (Phase 2) } \\
\hline & Mean \pm SEM & $\%$ Inhibition & Mean \pm SEM & $\%$ Inhibition & Mean \pm SEM & $\%$ Inhibition \\
\hline \multicolumn{7}{|l|}{$\mathrm{HF}$} \\
\hline $500 \mathrm{mg} / \mathrm{kg}$, po & $10.48 \pm 2.82^{*}$ & $66.8 \%$ & $27.35 \pm 5.06^{*}$ & $53.2 \%$ & $19.87 \pm 11.09^{*}$ & $77.7 \%$ \\
\hline $250 \mathrm{mg} / \mathrm{kg}$, po & $13.56 \pm 4.32^{*}$ & $57.0 \%$ & $26.29 \pm 4.36^{*}$ & $55.0 \%$ & $33.88 \pm 11.95^{*}$ & $62.0 \%$ \\
\hline $125 \mathrm{mg} / \mathrm{kg}$, po & $20.36 \pm 3.68^{*}$ & $35.6 \%$ & $27.90 \pm 12.53^{*}$ & $52.3 \%$ & $30.45 \pm 12.39^{*}$ & $65.9 \%$ \\
\hline $62.5 \mathrm{mg} / \mathrm{kg}$, po & $28.30 \pm 5.74$ & $10.3 \%$ & $62.17 \pm 9.59$ & - & $61.08 \pm 9.11$ & $31.6 \%$ \\
\hline Vehicle $(0.1 \mathrm{~mL} / 10 \mathrm{~g}, p o)$ & $33.15 \pm 1.31$ & - & $60.02 \pm 3.25$ & - & $83.35 \pm 11.62$ & - \\
\hline Morphine $(2.5 \mathrm{mg} / \mathrm{kg}, \mathrm{sc})$ & $5.50 \pm 0.55^{\star}$ & $83.2 \%$ & $10.10 \pm 3.34$ & $83.2 \%$ & $6.52 \pm 4.11^{*}$ & $92.2 \%$ \\
\hline
\end{tabular}

Animals $(\mathrm{N}=6-7)$ received formalin $(2 \%, 20 \mu \mathrm{L} / \mathrm{paw}, \mathrm{ip} /)$ or capsaicin $(20 \mu \mathrm{L}, 2 \mu \mathrm{g} / \mathrm{paw}) 60 \mathrm{~min}$ after HF $(62.5-500 \mathrm{mg} / \mathrm{kg}$, po) or vehicle $(0.1 \mathrm{~mL} / 10 \mathrm{~g}, p o)$. The licking time was quantified over a period of 0-5 min (first phase) and 15-30 min (second phase) in the formalin test or $5 \mathrm{~min}$ in the capsaicin test. Data are reported as means \pm SEM licking time (s). * $\mathrm{P}<0.05$ compared to vehicle (one-way ANOVA, Bonferroni's test).

The mean \pm SEM in the rotarod task was $59.33 \pm 5.57 \mathrm{~s}$ for $\mathrm{HF}$ and $71.42 \pm 8.94 \mathrm{~s}$ for the vehicle. In the locomotor activity, the mean \pm SEM number of crossings was 58.16 \pm 1.83 and $56.32 \pm 2.11$ for HF and vehicle, respectively. Diazepam (4 mg/kg, sc) was effective in the rotarod test $(23.33 \pm 9.38 \mathrm{~s})$ and open field $(15.71 \pm 15.19$ number of crossings) compared to vehicle.

\section{Discussion}

The importance of the present study lies in the assessment of the antinociceptive effect of the HF and its component, EPI, obtained from the bark of C. leprosum, and the mechanisms involved in the effect of this herbal preparation, which would justify future use of this species as a possible analgesic. It has been shown that EPI-like substances have anti-inflammatory activity, and this could be extended to EPI and thus explain its activities in models with inflammatory components, such as formalin or abdominal writhings (17).

Our results show that HF and EPI have an antinociceptive effect on formalin-induced nociception. The injection of formalin produces a biphasic behavioral response in which the first phase ( 0 to $5 \mathrm{~min}$ ) is characterized by the occurrence of neurogenic pain and the second phase (15 to $30 \mathrm{~min}$ ) is characterized by peripheral inflammation after a period of central sensitization $(13,18,19)$. In the second phase, there is an increase in spinal levels of several excitatory mediators such as glutamate, PGE2 and NO, among others $(4,18,20,21)$.

HF had an effect in two phases of the response, but EPI was effective only in the second phase. Bradykinin antagonists reverse the response in the first phase of the test, which shows that this mediator plays an important role in this step. On the other hand, anti-inflammatory drugs such as indomethacin and naproxen, or even drugs that interfere with the action of serotonin or histamine, are only effective in the second phase of this model, which suggests the involvement of different mediators at different times of the process $(19,22)$.

Therefore, we can assume that, at the dose of $25 \mathrm{mg} /$ $\mathrm{kg}$, EPI did not interfere with bradykinin, but only with the agents that participate in the second phase of the formalin test. The antinociceptive effects of HF were reversed by antagonists of serotonin receptors, which shows that its components act on this mediator. On the other hand, the fact that $50 \mathrm{mg} / \mathrm{kg}$ EPI did not cause similar effects can be explained by the hormesis or U-shaped phenomenon, whereby the increase in dose can decrease the pharmacological effect, which can only be achieved with lower or intermediate doses (23).

The capsaicin test was carried out to strengthen the hypothesis that the HF components could act to prevent the activation of nociceptors. Capsaicin has the ability to activate $\mathrm{C}$ or $\mathrm{A} \delta$ fibers in afferent neurons through stimulation of TRPV receptors, allowing the influx of $\mathrm{Ca}^{2+}$ and $\mathrm{Na}^{+}$ and lead to neurogenic pain (20). The results showed that the HF had a significant effect, suggesting the possibility of antagonism against the peripheral or central vanilloid receptors. Studies have shown that activation of these receptors causes a sharp increase in inflammatory mediator levels, as well as glutamate, supporting the results in the formalin test for HF $(14,24,25)$.

$\mathrm{HF}$ and EPI are also effective in the glutamate model. Studies have shown that glutamate is involved in nociceptive transmission from primary afferent fibers and in the develop- 
ment and maintenance of the pain response. Other findings show that glutamate acts on NMDA receptors located in peripheral, spinal and supraspinal structures, which are linked to the spinal release of $\mathrm{NO}(26,27)$. Thus, the possibility of blocking glutamate receptors by HF components and EPI could explain the effect of these extracts in this model as well as in the capsaicin and formalin models, considering that such substances lead to an increase of this spinal excitatory amino acid $(14,24,26,27)$.

$\mathrm{HF}$ and EPI have similar antinociceptive effect in the model of acetic acid-induced writhing in mice, suggesting that EPI is one of the constituents responsible for this effect. This test is a typical model of inflammatory pain, widely used to screen for new agents with peripheral analgesic and anti-inflammatory activity $(14,28)$. Afferent C-fibers located at cutaneous and visceral levels are activated $(13,14,25)$. Some studies show that nociception induced by acetic acid leads to a local release of cytokines such as TNF- $\alpha$, IL-1 $\beta$ and IL-8 from resident cells, as well as prostaglandin E2 $(29,30)$. The antinociceptive effect of HF and EPI could involve inhibition of the synthesis of these mediators or inhibition of sensory C-fibers. The suppression of the capsaicin-induced response and of the acetic acid-induced writhing by $\mathrm{HF}$ and $\mathrm{EPI}$ is a complementary indication that their antinociceptive action is observed when the noxious stimulus is conducted mainly by C-fibers (28).

In the model of glutamate-induced nociception, the role of the L-arginine/NO pathway in the effect of HF was assessed by pretreating the animals with a precursor of NO synthesis (L-arginine). There was a reversal of the HF effect, which corroborates the possibility of blocking NMDA receptors. The activation of postsynaptic NMDA receptors leads to increased calcium influx, activation of NO synthase, NO formation from L-arginine and cyclic GMP, which increases the conduction of the pain stimulus and maintains hyperalgesia $(24,26,31)$. Considering the possibility of blocking glutamate receptors, this would justify the results obtained with this model as well as those of the capsaicin test and in the second phase of the formalin test

\section{References}

1. Facundo VA, Andrade CHS, Silveira ER, Braz-Filho R, Hufford C. Triterpenes and flavonoids from Combretum leprosum. Phytochemistry 1993; 32: 411-515.

2. Pietrovski EF, Rosa KA, Facundo VA, Rios K, Marques $M C$, Santos AR. Antinociceptive properties of the ethanolic extract and of the triterpene 3beta,6beta,16beta-trihydroxylup-20(29)-ene obtained from the flowers of Combretum leprosum in mice. Pharmacol Biochem Behav 2006; 83: 90-99.

3. Lira SRS, Almeida RN, Almeida FRC, Oliveira FS, Duarte JC. Preliminary studies on the analgesic properties of the ethanol extract of C. leprosum. Pharm Biol 2002; 40: 213215. where there was also an increase of this spinal excitatory amino acid $(14,24)$.

Besides the aforementioned mechanisms, the antinociceptive action of HF may also involve the adrenergic and serotonergic systems. Pretreatment of animals with yohimbine, an $\alpha 2$ adrenergic antagonist and ketanserine, a $5-\mathrm{HT}_{2 \mathrm{~A}}$ antagonist, significantly reversed the antinociception caused by HF in the abdominal writhing model. Serotonin plays an important role in nociception control. However, the actions of serotonin in the spinal cord are complex and depend on the type of receptor and interaction with other routes and may have pro-nociceptive or antinociceptive effects. The activation of $5-\mathrm{HT}_{2}$ receptors would produce antinociception $(14,32)$. Thus, the components of the HF could be acting as $5-\mathrm{HT}_{2}$ agonists, considering that the use of an antagonist of these receptors partly reversed the effect of HF. The activation of serotonin receptors increases the release of noradrenaline in the spinal cord leading to antinociception through the activation of postsynaptic $\alpha 2$ receptors, and their antagonists (yohimbine) decrease this action as also do $5-\mathrm{HT}_{2}$ receptor antagonists $(32,33)$.

Naloxone did not reverse the antinociceptive effect of $\mathrm{HF}$, which therefore excludes the participation of the opioid system in the mediation of this effect. Similarly, such effect did not involve serotonin $5-\mathrm{HT}_{3}$, adenosine (A1 and $\left.\mathrm{A} 2\right)$ or acetylcholine (muscarinic) receptor activation since it remained unaffected by ondansetron, caffeine and atropine, respectively. It is unlikely that the effects observed with the HF are due to its putative muscle relaxant or central depressant activities since HF was unable to alter motor behavior or locomotor activity in the rotarod and open-field tests when compared to animals that received vehicle (control group).

The HF of the ethanol extract from the bark of $C$. leprosum has an antinociceptive effect in chemical models of nociception induced by different substances. This effect involves the participation of serotonergic and adrenergic receptors and the NO pathway and may be attributed partially to its component, EPI.
4. Nunes PH, Cavalcanti PM, Galvao SM, Martins MC. Antiulcerogenic activity of Combretum leprosum. Pharmazie 2009; 64: 58-62.

5. Eloff JN, Katerere DR, McGaw LJ. The biological activity and chemistry of the southern African Combretaceae. $J$ Ethnopharmacol 2008; 119: 686-699.

6. Ayres MCC. Isolamento e monitoramento de substâncias antioxidantes de Terminalia fagifolia e Combretum leprosum (Combretaceae). [Master's thesis]. Teresina: Departamento de Química UFPI; 2008. http://capesdw.capes.gov.br/ capesdw/resumo.html?idtese $=2008821001014003 P 9$

7. Baba S, Osakabe N, Natsume M, Muto Y, Takizawa T, Terao J. In vivo comparison of the bioavailability of (+)-catechin, 
(-)-epicatechin and their mixture in orally administered rats. J Nutr 2001; 131: 2885-2891.

8. Kim TH, Lim JM, Kim SS, Kim J, Park M, Song JH. Effects of (-) epigallocatechin-3-gallate on $\mathrm{Na}^{+}$currents in rat dorsal root ganglion neurons. Eur J Pharmacol 2009; 604: 20-26.

9. Zimmermann M. Ethical guidelines for investigations of experimental pain in conscious animals. Pain 1983; 16: 109-110.

10. Galotta ALQA, Boaventura MAD, Lima LARS. Antioxidant and cytotoxic activities of 'açaí' (Euterpe precatoria Mart.). Quim Nova 2008; 31: 1427-1430.

11. Mahato SB, Kundu AP. ${ }^{13} \mathrm{C}$ NMR-spectra of pentacyclic triterpenoids - a compilation and some salient features. Phytochemistry 1994; 37: 1517-1575.

12. Abrahamse S, Kloots WJ, Amelsvoort JMM. Absorption, distribution, and secretion of epicatechin and quercetin in the rat. Nutri Res 2005; 25: 305-331.

13. Le Bars D, Gozariu M, Cadden SW. Animal models of nociception. Pharmacol Rev 2001; 53: 597-652.

14. Santos AR, Gadotti VM, Oliveira GL, Tibola D, Paszcuk AF, Neto $A$, et al. Mechanisms involved in the antinociception caused by agmatine in mice. Neuropharmacology 2005; 48: 1021-1034.

15. Luiz AP, Moura JD, Meotti FC, Guginski G, Guimaraes CL, Azevedo MS, et al. Antinociceptive action of ethanolic extract obtained from roots of Humirianthera ampla Miers. $J$ Ethnopharmacol 2007; 114: 355-363.

16. Lopes LS, Pereira SS, Silva LL, Figueiredo KA, Moura BA, Almeida FR, et al. Antinociceptive effect of topiramate in models of acute pain and diabetic neuropathy in rodents. Life Sci 2009; 84: 105-110.

17. Vafeiadou K, Vauzour D, Lee HY, Rodriguez-Mateos A, Williams RJ, Spencer JP. The citrus flavanone naringenin inhibits inflammatory signalling in glial cells and protects against neuroinflammatory injury. Arch Biochem Biophys 2009; 484: 100-109.

18. Negus SS, Vanderah TW, Brandt MR, Bilsky EJ, Becerra L, Borsook D. Preclinical assessment of candidate analgesic drugs: recent advances and future challenges. J Pharmacol Exp Ther 2006; 319: 507-514.

19. Damas J, Liegeois JF. The inflammatory reaction induced by formalin in the rat paw. Naunyn Schmiedebergs Arch Pharmacol 1999; 359: 220-227.

20. Goudet C, Chapuy E, Alloui A, Acher F, Pin JP, Eschalier A. Group III metabotropic glutamate receptors inhibit hype- ralgesia in animal models of inflammation and neuropathic pain. Pain 2008; 137: 112-124.

21. Gonzalez-Trujano ME, Pena EI, Martinez AL, Moreno J, Guevara-Fefer P, Deciga-Campos M, et al. Evaluation of the antinociceptive effect of Rosmarinus officinalis $L$. using three different experimental models in rodents. J Ethnopharmacol 2007; 111: 476-482.

22. Shibata M, Ohkubo T, Takahashi H, Inoki R. Modified formalin test: characteristic biphasic pain response. Pain 1989; 38: 347-352.

23. Calabrese EJ, Baldwin LA. Hormesis: U-shaped dose responses and their centrality in toxicology. Trends Pharmacol Sci 2001; 22: 285-291.

24. Sakurada T, Sugiyama A, Sakurada C, Tanno K, Sakurada $\mathrm{S}$, Kisara $\mathrm{K}$, et al. Involvement of nitric oxide in spinally mediated capsaicin- and glutamate-induced behavioural responses in the mouse. Neurochem Int 1996; 29: 271-278.

25. Gunthorpe MJ, Benham CD, Randall A, Davis JB. The diversity in the vanilloid (TRPV) receptor family of ion channels. Trends Pharmacol Sci 2002; 23: 183-191.

26. Beirith A, Santos AR, Calixto JB. Mechanisms underlying the nociception and paw oedema caused by injection of glutamate into the mouse paw. Brain Res 2002; 924: 219-228.

27. Bleakman D, Alt A, Nisenbaum ES. Glutamate receptors and pain. Semin Cell Dev Biol 2006; 17: 592-604.

28. Jurgensen S, DalBo S, Angers P, Santos AR, Ribeiro-doValle RM. Involvement of 5-HT2 receptors in the antinociceptive effect of Uncaria tomentosa. Pharmacol Biochem Behav 2005; 81: 466-477.

29. Ribeiro RA, Vale ML, Thomazzi SM, Paschoalato AB, Poole $\mathrm{S}$, Ferreira $\mathrm{SH}$, et al. Involvement of resident macrophages and mast cells in the writhing nociceptive response induced by zymosan and acetic acid in mice. Eur J Pharmacol 2000; 387: 111-118.

30. Gomes NM, Rezende CM, Fontes SP, Matheus ME, Fernandes PD. Antinociceptive activity of Amazonian Copaiba oils. J Ethnopharmacol 2007; 109: 486-492.

31. Urban MO, Gebhart GF. Central mechanisms in pain. Med Clin North Am 1999; 83: 585-596.

32. Sawynok J, Reid A. Interactions of descending serotonergic systems with other neurotransmitters in the modulation of nociception. Behav Brain Res 1996; 73: 63-68.

33. Carrol I, Mackey S, Gaeta R. The role of adrenergic receptors and pain: The good, the bad, and the unknown. $S$ Anesth 2007; 26: 17-21. 